\title{
Deoxyribonucleic Acid Restriction Endonuclease Fingerprint Characterization of Actinomycete Strains
}

\author{
RETO CRAMERI, GILBERTO HINTERMANN, AND RALF HÜTTER* \\ Mikrobiologischés Institut, Eidgenössische Technische Hochschule Zentrum, CH-8092 Zurich, Switzerland
}

\begin{abstract}
Restriction endonuclease digestion of total purified genomic deoxyribonucleic acid gives rise to deoxyribonucleic acid fragments of discrete sizes. These can be separated by one-dimensional agarose gel electrophoresis. A unique banding pattern (fingerprint) is obtained for each actinomycete wild-type strain tested. These fingerprints are useful for recognizing a given wild-type strain and its derivatives, but cannot be used for species characterization.
\end{abstract}

Properties of genetic material have long been used as systematic criteria. Initially, organisms were characterized by the guanine-plus-cytosine contents of their deoxyribonucleic acids (DNA) (12-14). Other methods frequently used were DNA-DNA hybridization $(5,20)$ and ribosomal ribonucleic acid-DNA hybridization $(6,22)$. The determination of guanine-plus-cytosine contents permitted only a very general grouping of strains, species, or genera having similar DNA base compositions within systematic groups, but hybridization experiments allowed differentiation of closely related organisms.

The specific fragmentation of DNA by restriction endonucleases and the separation of the fragments by agarose gel electrophoresis furnish additional tools for DNA characterization. The use of this procedure in systematics is based on the following facts: (i) due to semiconservative DNA replication (16) the base sequence in the DNA of any organism is constant; (ii) the DNA of any organism contains specific base sequences which can be cut by suitable restriction endonucleases $(3,17)$; (iii) except in specific cases, mutational events do not alter the restriction fragment distribution (10); and (iv) culture conditions or age of culture at the time of harvest do not influence the restriction fragment pattern (10). Restriction endonuclease analysis has been used for virus identification in several instances, but the application of this method to bacteriological problems has been rare (15).

In this paper we show that restriction fragment analysis of the total chromosomal DNAs of actinomycete strains by one-dimensional agarose gel electrophoresis generates a reproducible and unique fingerprint for each organism. This technique is useful for tracing mutant strains to a given parent, but does not permit species characterization.

Bacterial strains and growth media. The strains used in this work are listed in Table 1. All
Streptomyces and Micromonospora strains were grown on yeast extract-malt extract agar slants (19) at $30^{\circ} \mathrm{C}$ until good sporulation occurred (4 to 10 days) and then stored at $4^{\circ} \mathrm{C}$.

Nocardia mediterranei strains were grown and stored as described previously (21). Mycelium for DNA isolation was obtained by using the appropriate liquid media, as described by Hintermann et al. (10).

Extraction and purification of DNA. Highmolecular-weight DNA was prepared as described by Hintermann et al. (10). The use of the rapid procedure enabled us to prepare pure DNA in 1 day. DNA was analyzed for the presence of plasmid DNA of discrete size by agarose gel electrophoresis (10) and the alkaline microscale method (2). Only DNA preparations without recognizable plasmid DNA were used for the experiments described below.

Restriction enzyme digestion of DNA and agarose gel electrophoresis. DNA digestions were carried out by using $10 \mathrm{U}$ of endonuclease BamHI (Boehringer, Mannheim, Federal Republic of Germany) per $\mu \mathrm{g}$ of DNA under the conditions recommended by the supplier.

One-dimensional agarose gel electrophoresis of the DNA restriction fragments was performed as described previously (10). Photographs were taken under ultraviolet illumination $(254 \mathrm{~nm})$ through a Wratten type 24A filter, using Kodak Royal Pan film.

Analysis of strains of Streptomyces. The restriction fragment distribution of each wild-type strain of Streptomyces was unique. Figure 1 shows the fingerprints of six wild-type strains of different species. Easily distinguishable banding patterns were observed. The banding patterns of the closely related strains "Streptomyces lividans" 130 (Fig. 1A, slot 3) and Streptomyces coelicolor A3(2) (Fig. 1A, slot 4) were very similar but not identical.

The major differences observed were most 
TABLE 1. Strains used in this study

\begin{tabular}{|c|c|c|c|c|}
\hline Organism & Strain $^{a}$ & Source $^{b}$ & Characterization & $\begin{array}{l}\text { Refer- } \\
\text { ence(s) }\end{array}$ \\
\hline Streptomyces coelicolor & $\mathrm{A} 3(2)$ & Hopwood & Wild type & \\
\hline Streptomyces glaucescens & GLA 0 & ETH 22794 & Wild type & \\
\hline "Streptomyces lividans" & $130^{d}$ & $\begin{array}{l}\text { Lomov- } \\
\text { skaya }\end{array}$ & Wild type & \\
\hline Streptomyces parvullus & 2283 & Hopwood & Wild type $\left(=\right.$ ATCC $\left.12434^{\mathrm{T}}\right)$ & \\
\hline Streptomyces noursei & $48240^{\mathrm{T}}$ & $\begin{array}{l}\text { ATCC } \\
11455^{\mathrm{T}}\end{array}$ & Wild type & \\
\hline Streptomyces peuceticus & 1762F.I. ${ }^{\mathrm{T} e}$ & Grein & Original daunorubicin producer & 8 \\
\hline $\begin{array}{l}\text { "Streptomyces peuceticus } \\
\text { subsp. caesius" }\end{array}$ & 106F.I. & Grein & High-producing variant of strain $1762 \mathrm{~F}$. I. $^{\mathrm{T}}$ & 1 \\
\hline "Streptomyces scabies" & A26 & Gregory & Wild type & \\
\hline $\begin{array}{l}\text { "Micromonospora } \\
\text { peucetica" }\end{array}$ & B211F.I.$^{f}$ & Grein & $\begin{array}{l}\text { Mutant derivative of strain 106F.I.; } \\
\text { producer of 11-deoxy analogs of } \\
\text { daunomicin }\end{array}$ & 4,7 \\
\hline Micromonospora species & B604F.I.$^{f}$ & Grein & $\begin{array}{l}\text { Producer of mixture of daunomicins and } \\
\text { 11-deoxy analogs }\end{array}$ & Grein $^{g}$ \\
\hline \multirow[t]{5}{*}{ Nocardia mediterranei } & $\mathrm{ME} / 83^{\mathrm{T} h}$ & Schupp & Wild type & \\
\hline & & Schupp & str-2 leu-2 ura-1 $c$ & \\
\hline & ATP118 & Schupp & Non-antibiotic-producing mutant & \\
\hline & W126 & Schupp & Producer of rifamycin $\mathrm{W}$ & \\
\hline & N813 & Schupp & High producer of rifamyin SV & \\
\hline
\end{tabular}

${ }^{a}$ All mutant strains of $N$. mediterranei were derived from strain $\mathrm{ME} / 83^{\mathrm{T}}$.

${ }^{b}$ ATCC, American Type Culture Collection, Rockville, Md.; ETH, Eidgenössische Technische Hochschule, Zurich, Switzerland; Hopwood, D. A. Hopwood, John Innes Institute, Norwich, United Kingdom; Lomovskaya, N. D. Lomovskaya, Institute of Genetics and Selection of Industrial Microorganisms, Moscow, Union of Soviet Socialist Republics; Gregory, K. F. Gregory, Department of Microbiology, University of Guelph, Guelph, Ontario, Canada; Grein, A. Grein, Farmitalia SpA, Milan, Italy; Schupp, T. Schupp, Ciba-Geigy AG, Basel, Switzerland.

c Genetic marker designations: str-2, resistance to $50 \mu \mathrm{g}$ of streptomycin per $\mathrm{ml}$; leu-2, leucine auxotrophy; ura-1, uracil auxotrophy; cys-3, cysteine auxotrophy; lys-1, lysine auxotrophy.

$d$ "S. lividans" strain 130 does not correspond to strain 66, which is usually used for genetic work, but is an independent wild-type isolate. It was chosen because results with DNA preparations from strain 66 were poorly reproducible due to strong nucleolytic activity.

${ }^{e} S$. peuceticus strain 1762 F.I. ${ }^{\mathrm{T}}$ was sent to us by A. Grein as the original strain of this species and should be identical to strain ATCC $29050^{\mathrm{T}}$.

${ }^{f}$ Micromonospora strains B211F.I. and B604F.I. were both derived from intermediate strain M78F.I., which was itself directly derived from ' $S$. peuceticus subsp. caesius' strain $106 \mathrm{~F}$.I. The parent strain of the Micromonospora strains (strain M78F.I.) was not available for analysis (A. Grein, personal communication).

${ }^{g}$ A. Grein, personal communication.

${ }^{h}$ N. mediterranei strain ME/83 ${ }^{\mathrm{T}}$ originally came from Lepetit SpA, Milan, Italy, as the wild-type isolate of this species and should be identical to strain ME83/973 $\left(=\right.$ ATCC $13685^{\mathrm{T}}$ ).

likely not due to the presence of plasmid DNA but were caused by differences in the chromosomal DNAs, as the DNA preparations used were previously checked for the absence of detectable plasmid DNA. However, interference of plasmid DNA cannot be completely excluded as an explanation for minor differences, as extrachromosomal DNA is not always readily recognizable in actinomycete DNA preparations. If analyses were performed with a strain set consisting of a plasmid-free parent and a derivative strain carrying a known plasmid, the fingerprints differed by distinct bands corresponding to plasmid DNA fragments; the intensities of these extra bands differed with the plasmid copy number (data not shown). It is possible that some differences in the banding pattern between closely related strains were caused by special modification systems, possibly comparable to the dam system of Escherichia coli (9). Therefore, for more detailed analyses, it will be necessary to use different restriction enzymes that yield a suitable size distribution of the DNA fragments.

However, the banding patterns differed among wild-type strains of a given species, as demonstrated for Streptomyces glaucescens by Hintermann et al. (10) and corroborated for other species (data not shown). In the case of the $S$. glaucescens strains investigated, the evidence indicated that the strains may not be as closely related as suggested by the species as- 

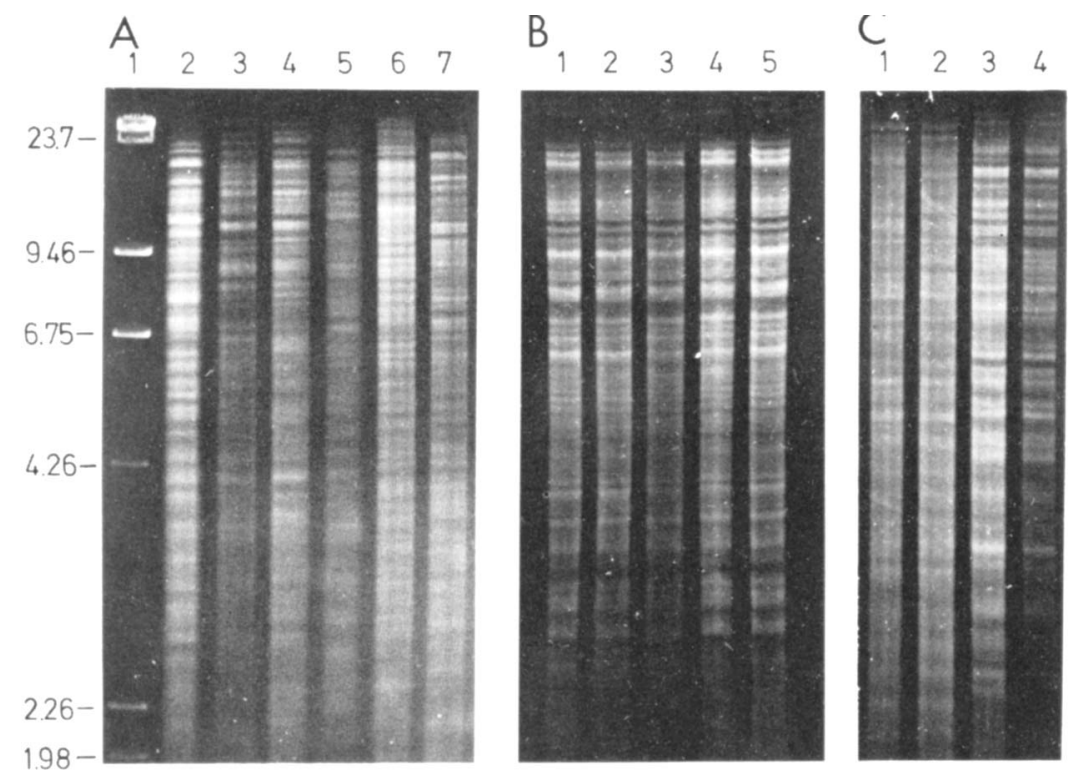

FIG. 1. (A) Agarose gels of BamHI restriction fragments of total genomic DNAs of different strains of Streptomyces. Slot 1, גDNA HindIII restriction fragments (fragment sizes [in kilobase pairs] [18] are indicated on the left); slot 2, S. glaucescens strain GLA O; slot 3, "S. lividans" strain 130; slot 4, S. coelicolor strain A3(2); slot 5, "S. scabies" strain A26; slot 6, S. noursei strain 48240; slot 7, S. parvullus strain 2283. (B) Agarose gels of Bam HI restriction fragments of $N$. mediterranei strains. Slot 1 , Wild-type strain $\mathrm{ME} / 83^{\mathrm{T}}$; slot 2 , mutant strain T96; slot 3, mutant strain ATP118; slot 4, mutant strain W126; slot 5, mutant strain N813. (C) Agarose gels of BamHI restriction fragments of anthracycline-producing $S$. peuceticus and Micromonospora strains. Slot 1 , " $S$. peuceticus subsp. caesius" strain 106F.I.; slot 2, S. peuceticus strain 1762F.I. '; slot 3, "M. peucetica" strain B211F.I.; slot 4, Micromonospora species strain B604F.I.

signment. Other strains did not produce the same antibiotics as strain GLA $\mathrm{O}$ and were not able to exchange genetic material in conjugational crosses with auxotrophic derivatives of strain GLA O (R. Crameri, Ph.D. thesis, Eidgenössische Technische Hochschule, Zurich, Switzerland, 1981).

Thus, the restriction fragment banding pattern in agarose gels is a strain-specific character and is not the same for all strains of a given species. With strains of Leptospira, Marschall et al. (15) have found that strains belonging to the same serovar produce identical restriction fragment patterns and that strains belonging to different serovars yield significantly different patterns. Thus, analyses of strains of Leptospira and Streptomyces lead in principle to the same conclusion.

Analysis of $N$. mediterranei. The restriction fragment patterns of the wild-type strain and some mutational and recombinational derivatives of $N$. mediterranei are shown in Fig. 1B. The banding pattern of this organism was constant, even in mutant strains developed for high rifamycin productivity. This finding is in agreement with the results obtained previously with S. glaucescens strain GLA O (10). In addition, the banding pattern for $N$. mediterranei did not vary with growth conditions or time of harvest (data not shown). We found no minor deviations in any of the $N$. mediterranei mutant strains tested, as was the case with special mutant strains of $S$. glaucescens $(10,11)$.

Thus, it can be concluded that restriction fragment distribution in agarose gels does not change significantly in mutant strains and can be used to trace strain history.

Problem of anthracycline-producing Streptomyces peuceticus and its derivatives. Repeated mutagenic treatments of "Streptomyces peuceticus subsp. caesius" gave mutant strain B211F.I, which produced four new glycosides of daunorubicin-related anthracyclines and exhibited morphological characteristics of Micromonospora (7). Strain B211F.I. and strain 604F.I, a similar strain also attributed to the genus Micromonospora, were compared with their grandparent strain, "S. peuceticus subsp. caesius" strain 106F.I., and the original $S$. peuceticus strain, strain 1762F.I. ${ }^{T}$ (type strain). Strain M78F.I., the parent from which mutant strains B211F.I. and 604F.I. were derived, could not be analyzed. The restriction fragment patterns of the total genomic DNAs of the $S$. peuceticus and 
Micromonospora strains showed clear and significant differences (Fig. 1C). Thus, it seems very unlikely that the Micromonospora strains mentioned above are mutational derivatives of $S$. peuceticus. However, the restriction endonuclease fingerprints of the two Micromonospora strains were virtually identical, suggesting a very close relationship between the two strains. That the two anthracycline-producing strain sets, one belonging to the genus Streptomyces and the other to the genus Micromonospora, are not closely related has already been suggested by analyses of cell wall compositions and fatty acid patterns (A. Grein, personal communication).

This work was supported by a research grant from the Swiss Federal Institute of Technology, Zürich.

\section{LITERATURE CITED}

1. Arcamone, F., G. Cassinelli, G. Fantini, A. Grein, P. Orezzi, C. Pol, and C. Spalla. 1969. Adriamycin, 14hydroxydaunomycin, a new antitumor antibiotic from $S$. peuceticus var. caesius. Biotechnol. Bioeng. 11:11011110.

2. Birnboim, H. C., and J. Doly. 1979. A rapid alkaline extraction procedure for screening recombinant plasmid DNA. Nucleic Acids Res. 7:1513-1523.

3. Brooks, J. E., and R. J. Roberts. 1982. Modification profiles of bacterial genomes. Nucleic Acids Res. 10:913-934.

4. Cassinelli, G., F. DiMatteo, S. Forenza, M. C. Ripamonti, G. Rivola, F. Arcamone, A. DiMarco, A. M. Casazza, C. Soranzo, and G. Pratesi. 1980. New anthracycline glycosides from Micromonospora. II. Isolation, characterization and biological properties. J. Antibiot. 33:1468-1473.

5. Doty, P., J. Marmur, J. Eigner, and C. Schildkraut. 1960. Strand separation and specific recombination in deoxyribonucleic acids: physical chemical studies. Proc. Natl. Acad. Sci. U.S.A. 46:461-476.

6. Gillespie, D., and S. Spiegelman. 1965. A quantitative assay for DNA-RNA hybrids with DNA immobilized on a membrane. J. Mol. Biol. 12:829-842.

7. Grein, A., S. Merli, and C. Spalla. 1980. New anthracycline glucosides from Micromonospora. I. Description of the producing strain. J. Antibiot. 33:1462-1467.

8. Grein, A., C. Spalla, A. DiMarco, and G. Canevazzi. 1963. Descrizione e classificazione di un attinomicete (Strepto- myces peuceticus sp. nova) produttore di una sostanza at attività antitumorale: la daunomicina. G. Microbiol. 11:109-118.

9. Hattman, S., J. E. Brooks, and M. Masurekar. 1978. Sequence specificity of the P1 modification methylase (M.EcoP1) and the DNA methylase (M.Ecodam) controlled by the Escherichia coli dam gene. J. Mol. Biol. 126:367-380

10. Hintermann, G., R. Crameri, T. Kieser, and R. Hütter. 1981. Restriction analysis of the Streptomyces glaucescens genome by agarose gel electrophoresis. Arch. Microbiol. 130:218-222.

11. Hintermann, G., R. Crameri, T. Kieser, and R. Hütter. 1982. A technique for the detection of large DNA alterations in complex genomes. Anal. Biochem. 121:327-330.

12. Lee, K. Y., R. Wahl, and E. Barbu. 1956. Contenu en base puriques et pyrimidiques des acides désoxyribonucléiques des bactéries. Ann. Inst. Pasteur Paris 91:212-224.

13. Mandel, M., C. L. Schildkraut, and J. Marmur. 1968. Use of $\mathrm{CsCl}$ density gradient for determining the guanine plus cytosine content of DNA. Methods Enzymol. 12B:184195.

14. Marmur, J., and P. Doty. 1962. Determination of the base composition of deoxyribonucleic acid from its thermal denaturation temperature. J. Mol. Biol. 5:109-118.

15. Marschall, R. B., B. E. Wilton, and A. J. Robinson. 1981 Identification of Leptospira serovars by restriction-endonuclease analysis. J. Med. Microbiol. 14:163-166.

16. Meselson, M., and F. Stahl. 1958. The replication of DNA in Escherichia coli. Proc. Natl. Acad. Sci. U.S.A. 44:671682.

17. Modrich, P. 1979. Structures and mechanisms of DNA restriction and modification enzymes. Q. Rev. Biophys. 12:315-369.

18. Phillipsen, P., R. A. Kramer, and R. W. Davis. 1978. Cloning of the yeast ribosomal DNA repeat unit in $S s t$ I and HindllI lambda vectors using genetic and physical size selections. J. Mol. Biol. 123:371-386.

19. Pridham, T. G., P. Anderson, C. Foley, L. A. Lindenfelser, C. W. Hesseltine, and R, G. Benedict. 1957. A selection of media for maintenance and taxonomic study of Streptomyces. Antibiot. Annu. 1956/57:947-953.

20. Schildkraut, C. L., J. Marmur, and P. Doty. 1961. The formation of hybrid DNA molecules and their use in studies of DNA homologies. J. Mol. Biol. 3:595-617.

21. Schupp, T., R. Hütter, and D. A. Hopwood. 1975. Genetic recombination in Nocardia mediterranei. J. Bacteriol. 121:128-136.

22. Stackebrandt, E., B. Wunner-Füssl, V. J. Fowler, and K. H. Schleifer. 1981. Deoxyribonucleic acid homologies and ribosomal ribonucleic acid similarities among sporeforming members of the order Actinomycetales. Int. J. Syst. Bacteriol. 31:420-431. 